\title{
Small Circulation, Big Impact: English Language Newspaper Readability in Bangladesh
}

\author{
Jude William Genilo ${ }^{*}$, Md. Asiuzzaman', Md. Mahbubul Haque Osmani² \\ ${ }^{1}$ Department of Media Studies and Journalism, University of Liberal Arts Bangladesh, Dhaka, Bangladesh \\ ${ }^{2}$ News and Current Affairs, NRB TV, Toronto, Canada \\ Email: *jude.genilo@ulab.edu.bd
}

How to cite this paper: Genilo, J. W., Asiuzzaman, Md., \& Osmani, Md. M. H. (2016). Small Circulation, Big Impact: English Language Newspaper Readability in Bangladesh. Advances in Journalism and Communication, 4, 127-148.

http://dx.doi.org/10.4236/ajc.2016.44012

Received: August 31, 2016

Accepted: December 27, 2016

Published: December 30, 2016

Copyright $\odot 2016$ by authors and Scientific Research Publishing Inc. This work is licensed under the Creative Commons Attribution International License (CC BY 4.0).

http://creativecommons.org/licenses/by/4.0/

\begin{abstract}
Academic studies on newspapers in Bangladesh revolve round mainly four research streams: importance of freedom of press in dynamics of democracy; political economy of the newspaper industry; newspaper credibility and ethics; and how newspapers can contribute to development and social change. This paper looks into what can be called as the fifth stream-the readability of newspapers. The main objective is to know the content and proportion of news and information appearing in English language newspapers in Bangladesh in terms of story theme, geographic focus, treatment, origin, visual presentation, diversity of sources/photos, newspaper structure, content promotion and listings. Five English-language newspapers were selected as per their officially published circulation figure for this research. These were the Daily Star, Daily Sun, Dhaka Tribune, Independent and New Age. The researchers did a content analysis of the front-page contents of five newspapers for a month. In this exploratory, descriptive and quantitative research, the instrument developed by the Readership Institute at the Northwestern University was modified and used. Data gathered were classified in four broad areas namely: 1) story analysis, 2) newspaper structure, 3) listings or types of content and 4) content promotion. The findings help understand the content of the English-language newspapers in terms of demographic and geographic focus, photo diversity, gender balance, news themes, news sourcing and news treatment. It also gives a clear picture of the newspaper structure in terms of space allocation for news and advertisement. In this manner, the newspaper industry will progress as it identifies problems and takes measures to remain relevant in a region where the print media are still on the rise although facing stiff competition from the electronic media and online news portals.
\end{abstract}

\section{Keywords}

Readability, Newspapers, Bangladesh 


\section{Introduction}

If one were to search for academic studies regarding newspapers in Bangladesh, one will find four dominant research themes. The first batch of literature shows the importance of a free press in ensuring a dynamic democracy and public sphere in the country (threats to this freedom such as censorship and killings of journalists being included here). The second group focuses on the political economy of the newspaper industry; describing its history, ownership structure and failure to live its role as the "fourth estate." Then, springing from critiques of journalism business models, the third cluster looks into newspaper credibility; indicating the lack of it given inherent bias towards powerful political parties and big conglomerates. With this, the fourth collection deals with how the press can contribute towards national development and social change; citing the forays of the industry towards various advocacies that are the social, economic and environmental aspects.

An apparent research gap in Bangladeshi journalism studies involves the more routine day-to-day aspect, particularly how the practice can be improved. As mentioned by Wimmer \& Dominick (1997), some practical studies in print media may include readership research (demographic and psychographic profiles), circulation research (number of editions and copies distributed), newspaper management research (reporter/ editor development and quality standard improvement), typography and make-up research (fonts, color and other visual elements) and readability research (the ease of reading the newspaper). These types of journalism studies have largely been ignored by Bangladeshi academicians. And, this is where the present study focuses on, specifically about the readability of English language newspapers in the country.

Before proceeding further, the authors discuss in brief the origin and growth of the newspaper industry, describe the leading English language newspapers and investigate the concept of readability in the context of newspapers.

\subsection{Origin, Struggle and Growth of Newspaper Industry}

The origin of the country's newspaper industry may be traced during British colonial times. In the late $18^{\text {th }}$ century, the Bengal Gazette or Hickey's Bengal Gazette (which was in English) was published in Kolkata. This weekly publication was to be the first newspaper of modern times in the Indian subcontinent. In 1818, Bengali newspapers started to appear-the monthly Digdarshan (1818), the weekly Samachar Darpan (1818), and the weekly Bengal Gazette (1818) (Haider, 2010).

In 1947, after British rule and with the partition of the sub-continent into India and Pakistan, there was a lack of newspapers in East and West Pakistan. However, newspapers which catered to Muslim readers in British India soon transferred their operations to Pakistan. In East Pakistan, Dainik Azad (Daily Freedom) shifted from Kolkata to Dhaka in 1948. In 1949, an English daily the Pakistan Observer (renamed as Bangladesh Observer after independence in 1971) was published from Dhaka. Two other newspapers, Dainik Sangbad (Daily News) and Dainik Ittefaq (Daily Unity) were brought out in 1949 and 1953 respectively. Ittefaq, which would later dominate the Bangladeshi 
press for decades, was first published as a weekly mouthpiece of the region's main political party the Awami League. These four dailies-Dainik Azad, The Pakistan (Bangladesh) Observer, Dainik Sangbad and Dainik Ittefaq together dominated Bangladeshi press sector for decades and may be regarded as pioneers of the national press system (Mahmud, 2013).

After its Independence in 1971, the Bangladeshi press enjoyed a brief honeymoon period with national leaders. The new national leaders consolidated their position and grew intolerant of criticisms from the press. In 1975, Sheikh Mujibur Rahman, the country's founding father, imposed a one-party presidential system, curtailed fundamental rights and banned all newspapers except four-Dainik Ittefaq, Dainik Bangla, Bangladesh Observer and Bangladesh Times. These newspapers were placed under strict government control and management. With the changeover in 1975 more newspapers were given licenses to operate but the succeeding authoritarian regimes-General Ziaur Rahman (1978-1981) and General Ershad (1981-1990)-continued the policy of strict censorship and regulation of the press. Any newspaper critical of military rulers was closed down.

In 1990, Bangladesh became a democratic country once again. With the change of political and socio-economic system, the private sector began to grow. This had positive implications for the newspaper industry. Mahmud (2013) identifies the following: First, democratic political culture provides the room for politicians to exploit mass media in order to create favourable opinion enabling them to win elections. Politicians are also more aware now about how to construct their positive images to enhance their appeal in elections. Secondly, emerging private sector or business people look to the media both as a means to sell their products and as a tool of power and prestige. Wealthy businessmen moved to media business for sustainability of their businesses, which later involved them in politics, capitalising the power of their media. Thirdly, economic progress and social development such as increased literacy rates and improved purchasing capacity allowed people to consume more media products. Business and service sectors targeted this burgeoning middle class as potential consumers of their products and services, and accordingly expanded advertisements to reach them.

WAN-IFRA (2015) reported that print circulation increased by 6.4 percent globally in 2014 from a year earlier and shows a five year growth of 16.5 percent. This is largely the result of circulation increases in India and elsewhere in Asia. In Bangladesh, the readership of newspapers is rising given increased purchasing power and improving literacy. In 2015, the country was among four nations that crossed over the critical line from the low-income to the lower-middle income category. Then, in June 2015, Education Minister Nurul Islam Nahid announced that the country enjoys a literacy rate of 70 percent-up from 55.08 percent in 2010 (Bangladesh Literacy Survey, 2010). The newspaper business in India and Bangladesh are among the healthiest print newspaper industries in the world.

With these, the newspaper industry in the country grew rapidly. Table 1 shows the circulation of top Bengali national dailies in the country as of 22 April 2014. 
Table 1. Circulation of top national dailies in Bangladesh.

\begin{tabular}{cc}
\hline Newspaper & Circulation \\
\hline Bangladesh Protidin & 553,150 \\
Prothom Alo & 501,750 \\
Kalerkontho & 250,600 \\
Dainik Jugantor & 221,125 \\
Dainik Ittefaq & 194,500 \\
Dainik Amader Somoy & 177,475 \\
Dainik Janokontho & 164,820 \\
Dainik Samakal & 164,250 \\
Dainik Manobkantha & 161,010 \\
Dainik Alokito Bangladesh & 151,650 \\
\hline
\end{tabular}

Source: Department of film and publications, information ministry of Bangladesh, 2014.

Many of the newspapers are financed by the country's large conglomerates-Beximco, Globe, Karnaphuli, Transcom, Jamuna, Ha-meen, Bashundara and Gemcon Group and Kazi Farm Group. Gemcon-Kazi Farm, in 2013, launched a English language newspaper Dhaka Tribune. The following year the same publisher launched a vernacular daily titled Bangla Tribune. In 30 May 2012, newspaper publishers held a meeting in Dhaka, which was organized by the World Association of Newspapers and Newspaper Publishers. During the workshop, it was projected that newspaper readership in South Asia will continue to grow. For this reason, we can expect more newspapers to be established in the country.

\subsection{The Rise of English Language Newspapers}

During the past two decades, Bangladeshi newspapers written in English have been increasing in terms of prominence and importance. These newspapers have found a niche among the elite, middle class and decision-makers of the country. Hence, they are considerably influential in spite of their smaller circulation figures. In light of this, readers witness The Daily Star taking on advocacy issues such as environmental conservation (Reza \& Haque, 2011), relentless campaigning against hartals or nationwide strikes as a form of protest and supporting creative pursuits such as art exhibitions. Rahman (2011) likewise points out that the newspaper published critical pieces against the rise of Islamic extremism in the country.

In the same manner, Dhaka Tribune has consistently covered events relating to the deteriorating quality of education in public universities and the urgency of women empowerment in the country. English language newspapers have likewise been in the forefront in covering business stories-The Daily Star being the first to have a separate section for business (first with four pages and later with eight pages). Aside from business, English language newspapers extensively feature cultural events such as visual exhibits, music concerts, foreign films, etc. 
Given its readership, the English language newspapers charge a higher premium for advertising space. For example, the Daily Star with a circulation of 41,150 charges BDT 13,500 (USD 171) per square inch for a front page advertisement while Prothom Alo with a circulation of 513,000 charges BDT 20,500 (USD 259) per square inch for a front page advertisement. They also have a presence in the Internet allowing them to reach audiences instantaneously. Table 2 shows the brief description of English-language newspapers in Bangladesh.

Table 2. Brief description of English-language newspapers in Bangladesh.

\begin{tabular}{|c|c|}
\hline Newspaper & Description \\
\hline The Daily Star & $\begin{array}{l}\text { The Daily Star was first published on } 14 \text { January 1991. Late S M Ali was founding } \\
\text { editor while A. S. Mahmood was the publisher. Mr Mahfuz Aanam was the } \\
\text { executive editor of the paper since its inception. After SM Ali passed away in 1993, } \\
\text { Mahfuz Anam became the editor of the newspaper. He is currently the editor cum } \\
\text { publisher of the newspaper. Along with its regular 24-page main section the } \\
\text { newspaper publishes different weekly sections almost day targeting a wide } \\
\text { range of readers. Their weekly and fortnightly sections include Weekend } \\
\text { magazine, Byte, Shift, Next Step, In Focus, Literature, Book Reviews, Health, } \\
\text { Science, Law \& Order, Wide Angle, Environment, Travel etc. Moreover, it } \\
\text { publishes supplements regularly on various occasions. Country's one of the } \\
\text { biggest conglomerate Transcom Group is the main financier of the publication. }\end{array}$ \\
\hline The Independent & $\begin{array}{l}\text { The Independent was published in } 26 \text { March } 1995 \text { as the first full-colour 32-page } \\
\text { English newspaper in Bangladesh. The first editor was Mahbubul Alam } \\
\text { Chowdhury who was succeeded by Mahbubul Alam, the longest serving } \\
\text { editor of the newspaper. The current editor and publisher is M. Shamsur } \\
\text { Rahman. The newspaper has reduced its regular section from 32-pages to } \\
\text { 24-pages. Its weekly and fortnightly sections include Art \& Culture, Technology, } \\
\text { Travel, Lifestyle, Education, Health, Environment, Science etc. One of the biggest } \\
\text { names in corporate world in Bangladesh, the Beximco Group, owns the newspaper. }\end{array}$ \\
\hline The Daily Sun & $\begin{array}{l}\text { The Daily Sun was published on } 20 \text { October } 2010 \text { with Prof Syed Anwar Hossain as } \\
\text { it first editor. The published was Maynal Hossain Chowdhury. The main paper is } \\
\text { of } 28 \text { pages including } 4 \text { pages of business and } 8 \text { pages of sports which they called } \\
\text { "Winner". Its weekly sections include Groove, The Hood + Brain Freeze, Morning } \\
\text { Tea. Another biggest conglomerate of the country with businesses ranging from } \\
\text { land and real estate to toilet tissue, the Bashundhara groups, owns the newspaper. }\end{array}$ \\
\hline New Age & $\begin{array}{l}\text { The New Age was published on } 7 \text { July } 2003 \text { by veteran journalist Enayetullah } \\
\text { Khan as editor. The current editor in Nurul Kabir and publisher is ASM } \\
\text { Shahidullah Khan who is a businessman and main financier of the newspaper. It is } \\
\text { regarded as one of the country's most outspoken newspapers and known for its } \\
\text { anti-establishment editorial policy. In late } 2014 \text { police attempted to search the } \\
\text { newspaper office without any search warrant but failed to do at the resistance of its } \\
\text { journalists and staff. Its weekly supplements include: TRENDS, NEWAGEXtra, } \\
\text { NEW AGE Youth, Paper for People etc. }\end{array}$ \\
\hline Dhaka Tribune & $\begin{array}{l}\text { Dhaka Tribune is the youngest mainstream daily newspaper in the country } \\
\text { published on } 19 \text { April 2013. Kazi Anis Ahmed is the publisher of the newspaper } \\
\text { while Zafar Sobhan serves as Editor. It's weekly and fortnightly sections include } \\
\text { Showtime, Fashion, Grooming, Wellness, Cars, Tech, Profiles, Shopping, Teen, } \\
\text { Food, Lifestyle, Relationship, Arts \& Culture. The newspaper started its journey as } \\
\text { a broadsheet but later converted to a tabloid or compact size. In terms of content } \\
\text { the daily managed to keep its broadsheet characteristics. Two big business } \\
\text { houses-the Gemcon Group and Kazi Farm Group, is the owner of the newspaper. }\end{array}$ \\
\hline
\end{tabular}




\subsection{Increasing Newspaper Readership}

Given the dominance of the corporate business model in the newspaper industry, it makes sense to look at quality as a determinant of readership. According to Meyer \& Kim (2003), "the connection between journalism quality and business success has long been a concern of media scholars. The problem has been called the profit controversy, the apparent conflict between managing high quality and making a profit." Some studies argue that high quality is related to readership and readership is related to profitability. To this, Meyer and Kim recommend looking at key factors determining newspaper quality-ease of use, localism, editorial vigor, news quantity and interpretation. But, some newspaper companies have begun to tailor their products to more specific audiences and increase profitability by reducing readership and circulation to customers less desired by advertisers.

Other studies suggest the concept of the sweet spot. i.e., the relationship between journalistic quality and business success is not linear. It probably follows a bell curve where quality is measured on the horizontal axis, profitability on the vertical. Increasing quality improves profitability up to the peak of the curve. Beyond that point, additional quality fails to bring enough new readers to add to the value of advertising or pricing power, and becomes net cost.

Nevertheless, after reviewing various measurements of newspaper quality, Lynch \& Peer (2002), suggest the use of content analysis to measure in a reliable manner what news and information are appearing in newspapers and in what proportions. In this manner, newspaper editors realize what makes readers more satisfied and can make informed decisions about resource allocation. They would be able to track content over time to measure readership-building changes.

The present paper, in light of this, endeavors to modify the content analysis methodology of Lynch and Peer in the context of Bangladesh English language newspapers. It seeks to understand what aspects may be undertaken to improve the readability of newspapers, particularly on content promotion, content diversity, photo diversity, use of graphics and photographs, use of listings, article titling, etc. The paper does not look into the ease of reading articles written in the said publications through the use of various readability measurements such as Flesch Test, Gunning Fog Index, Cloze Procedure, etc.

\section{Problem Statement}

What is the general structure of five select Bangladeshi English language newspapers? What content characteristics promote the readability of the said newspapers?

\section{Study Objectives}

The objectives of the study are as follows:

- To find out the general structure of five select Bangladeshi English language newspapers in terms of number of pages, sections, stories and advertisements (classified and display); and 
- To know the content and proportion of news, visuals and information that promote the readability of the said newspapers in terms of story theme, geographic focus, treatment, origin, visual presentation, diversity of sources/photos, content promotion and listings.

\section{Literature Review}

The literature reviewed for this study may be divided into two types: (1) concepts of print newspaper readability; and (2) readability studies conducted based on these concepts. Combing through the literature, one would find two basic understandings of readability-one limited to the text and the other one more inclusive as it also looks at the total make-up of the newspaper. This paper utilizes the second understanding of readability. Kondur (2006), Richards et al. (1992) and McLaughlin (1969) provide the original concept of readability, which is to evaluate the reading difficulty of a text (such as a news article). McLaughlin (1969) defines readability as the level to which a given class of people can come across certain reading matter persuasive and understandable. And based on this, educators decide on suitable texts for students and authors write texts easy to set to the target audience (Kondur, 2006). Richards et al. (1992) even discuss factors that affect readability such as the average length of sentences, the number of new words contained and the grammatical complexity of the language used in a passage. Seaton (1975 cited in Rezaei, 2000) add other linguistic factors such as lengthwise measurement of words and sentences. Readability depends on the comprehensibility of a piece of writing.

On the other hand, Dale \& Chall (1949) explained readability in an inclusive way. They stated that readability refers to the sum total of all the elements including their interactions that has an effect on the success of a piece of printed material. For example, the readability of a print newspaper depends on many internal and external factors such as the content of the subject-matter and theme, clarity and color of printing and illustrations, the length of the subject-matter, the total get-up of the newspaper, etc. Sometimes, personal taste of a reader determines whether a newspaper is readable or not. Moreover, interest in particular news or other items is not the only yardstick to measure the readability. The style of writing constitutes the ease to read or understand it.

The present paper then reviewed studies relating to the two concepts of readability. Under the first readability concept, Coulson \& Hansen (1995) studied the news content of the Louisville Courier-Journal after its acquisition by the Gannett organization. Results showed that the total amount of news space increased but that the average length of stories and the amount of hard news coverage decreased. To examine the quality of publications, Coulson (1994) sampled 773 journalists at independent and group-owned newspapers. Most of the journalists at independently owned papers rated their paper's promise to quality local coverage as excellent.

Under the second concept, Lynch \& Peer (2002) provided a guide on "Analyzing Newspaper Content: A How-To Guide" for the Readership Institute of Northwestern 
University. The guide describes the process of establishing reliable measures of what news and information is appearing in a newspaper and in what proportions. It uses the content analysis method and is purportedly well-tested. By analyzing newspaper content, one would be able to measure readership-building challenges-thereby increasing the readability of the newspaper.

There have been several content analysis conducted in Bangladesh in the past. However, as mentioned in the introduction, these were not for the purpose of content analysis. Rather, these were for analyzing newspaper credibility, contribution to national development, efforts towards being a watchdog of democracy, etc.

\section{Study Framework}

This paper basically looks at the readability of English Language newspapers in Bangladesh-utilizing the more inclusive definition of readability. As such, it studies the sum total of all the elements of a newspaper, which are represented in Diagram 1.

Based on the framework, readability is the sum of the newspaper's total make up in achieving diversity, using visuals, promoting content and article readability. Diversity

\begin{tabular}{|c|c|}
\hline \multirow[t]{4}{*}{$\begin{array}{l}\text { Readability } \\
\text { (sum total of all the elements of a } \\
\text { newspaper) }\end{array}$} & $\begin{array}{l}\text { Diversity } \\
\begin{array}{l}\text { - Section } \\
\text { - Source } \\
\text { - News Origin } \\
\text { - Geographic Focus } \\
\text { - Theme/Treatment } \\
\text { - Photograph }\end{array}\end{array}$ \\
\hline & $\begin{array}{l}\text { Use of Visuals } \\
\begin{array}{l}\text { - } \text { Graphics } \\
\text { - Photographs } \\
\text { - Listings }\end{array}\end{array}$ \\
\hline & $\begin{array}{l}\text { Content Promotion } \\
\begin{aligned} \text { - General } \\
\text { - Same Day } \\
\text { - Upcoming } \\
\text { - Web }\end{aligned}\end{array}$ \\
\hline & $\begin{array}{l}\text { Story Readability Analysis } \\
\text { - Use of Jumps } \\
\text { - Story Title Length }\end{array}$ \\
\hline
\end{tabular}

Diagram 1. Study framework showing sum total of readability. 
improves readability since it can attract a wider spectrum of audiences. Diversity can be seen from the newspaper's editorial content (section, source, news origin, geographic focus, theme and treatment) as well as its photographs. If the newspaper had a greater inventory of sections, it would attract greater readership. Lynch \& Peer (2002) lists sections to include sports, business, food, lifestyle, entertainment, education, books, fashion, science, health, travel, comics, family, youth, home and garden, etc. Aside from this, readability may improve if a story has a diversity of sources (unidentified, politician/celebrity, male, female, ordinary people, etc.), news origin (news agency, staff, reader, editor, columnist, contributor, etc.), geographic focus (capital, division, national, regional, international, etc.), treatment (hard news, news feature, commentary, news analysis, investigative news, etc.) and theme (politics, police/crime, business, sports, etc.). For diversity in photographs, it would include faces that are visible, ethnic, Bengali, male, female and of children.

The use of visuals likewise improves the readability of newspapers given its benefits of simplicity, immediacy and flexibility. Usually, visuals utilized include graphics, photographs and listings. Lynch \& Peer (2002) define listings as editorial content that is not a story, not a paid advertisement, presented as a collection of numbers and other information and is not in complete sentences. Examples of these are stock market lists, television schedules, movies shown in cinemas, etc. Graphics, on the other hand, include graphs, charts and any non-photograph visuals used to help tell the story.

Also, readers get attracted to newspapers if they know the content in the current or future issue. There are basically three ways newspapers promote their content. First, newspapers promote the newspaper as a whole; positioning their editorial stance via taglines and catchy phrases. General content promotion does not promote a particular story or issue; just encouraging people to read the newspaper. Second, newspapers can promote particular content such as special features or investigative news. They promote particular content either a few days in advanced or on the same day. Third, newspapers promote the content of their online or web versions.

Although there are many measures of story readability, only two were considered in this study-use of jumps and story title length. A story is said to have "jumped" when it is continued on another page. Usually, newspapers give an instruction such as "see... in page..." Jumps usually decrease readability. Story title length refers to the number of words used in the story title. A shorter title usually increases ease in readability. As stated earlier, there are other readability measurements, particularly with regard to texts of stories. These, however, were not investigated in the present study.

\section{Method and Design}

The research is exploratory, descriptive and quantitative. It utilized the content analysis research method, the procedure of which was modified from Lynch \& Peer (2002) who wrote the "Analyzing Newspaper Content: A How-To Guide" for the Readership Institute of Northwestern University. The content analysis consisted of four parts: 1) story analysis, 2) newspaper structure, 3) listings or types of content and 4) content 
promotion. The English language newspapers included in the study are: Daily Star, Daily Sun, New Age, Independent and Dhaka Tribune. They were selected due to their circulation figure, i.e., the most widely circulated English-language newspapers in the country.

The following data gathering procedures were followed in the study:

- In April 2015, the authors reviewed and modified the coding sheets of the Readership Institute to fit the context of Bangladesh. For example, instead of retaining visible white faces in photographs, they placed visible Bengali faces.

- In May and June 2015, the authors announced the need for coders. Several responded to the announcement and after interviews, five were selected. The coders had a background in either media, journalism or business.

- In July and August, the coders were given training on doing the different types of content analysis. An intercoder reliability test was conducted by the end of August but the result was only 50 percent. Another two trainings were conducted in September and October. Another intercoder reliability test was taken at the end of October but the result improved slightly at $65 \%$. The authors then decided to drop two coders-the weakest ones in the group.

- In November, another training was conducted and at the end of which the intercoder reliability test drastically improved to $90 \%$. In December, the three coders were given copies of the five select newspapers for the entire month of November 2015.

- In March 2016, the four coders completed the coding sheets for the different types of content analysis for the five select newspapers. The coding sheets were then encoded and tabulated using MS Excel by a research assistant-who completed the entire process in May 2016. The authors then checked and edited the work of the research assistant in June 2016.

\section{Variables and Measures}

The matrix below shows the variables and measures used in the study (Table 3).

\section{Results and Discussion}

The section is divided into the following parts: 1) newspaper profile and structure; 2) newspaper content diversity; 3) use of visuals; 4) content promotion; and 5) story readability analysis.

\section{Newspaper Profile and Structure}

The sub-section presents the general profile and structure of the select English-language newspapers. Among the five, Daily Star started first in 1991, followed by Independent (1995) and New Age (2003). The newer papers are Daily Sun and Dhaka Tribune founded in 2010 and 2013 respectively. Given that it went ahead, Daily Star has the largest circulation (41,150 copies). The others have claimed to be a circulation from 23,000 to 28,500 copies. Except for New Age, all newspapers are owned by large business 
Table 3. Variables, indicators and measures of the study.

\begin{tabular}{|c|c|c|}
\hline Variables & Indicators & Measurement \\
\hline \multirow{8}{*}{ Diversity } & Section Diversity & $\begin{array}{l}\text { Percentage and type of sections (city, business, } \\
\text { sports, etc.) of the front page of newspaper }\end{array}$ \\
\hline & Source Diversity & $\begin{array}{l}\text { Percentage and type of front page story news } \\
\text { source (unidentified, politician/celebrity, male, } \\
\text { female, ordinary people, etc.) }\end{array}$ \\
\hline & News Origin Diversity & $\begin{array}{l}\text { Percentage and type of front page story news } \\
\text { origin (news agency, staff, reader, editor, } \\
\text { columnist, contributor, etc.) }\end{array}$ \\
\hline & Geographic Focus Diversity & $\begin{array}{l}\text { Percentage and type of front story geographic } \\
\text { focus (capital, division, national, regional, } \\
\text { international, etc.) }\end{array}$ \\
\hline & Treatment Diversity & $\begin{array}{l}\text { Percentage and type of front story treatment } \\
\text { (hard news, news feature, commentary, news } \\
\text { analysis, investigative news, etc.) }\end{array}$ \\
\hline & Theme Diversity & $\begin{array}{l}\text { Percentage and type of front story theme } \\
\text { (politics, police/crime, business, sports, etc.) }\end{array}$ \\
\hline & Photo Diversity & $\begin{array}{l}\text { Percentage of photos with faces that are visible, } \\
\text { ethnic, Bengali, male, female and of children. }\end{array}$ \\
\hline & Use of Graphics & $\begin{array}{l}\text { Percentage of newspaper issues with } \\
\text { graphics in the front page }\end{array}$ \\
\hline \multirow[t]{2}{*}{ Use of Visuals } & Use of Photographs & $\begin{array}{l}\text { Percentage of newspaper issues with and } \\
\text { area (in square inches) devoted to } \\
\text { photographs in the front page }\end{array}$ \\
\hline & Use of Listings & $\begin{array}{l}\text { Percentage of newspaper issues with and } \\
\text { area (in square inches) devoted to listings }\end{array}$ \\
\hline \multirow{2}{*}{$\begin{array}{l}\text { Content } \\
\text { Promotion }\end{array}$} & $\begin{array}{c}\text { General Promotion } \\
\text { Same Day Content Promotion }\end{array}$ & $\begin{array}{l}\text { For all sub-indicators: } \\
\text { - Number and type of content promoted }\end{array}$ \\
\hline & $\begin{array}{l}\text { Upcoming Content Promotion } \\
\text { Website Content Promotion }\end{array}$ & $\begin{array}{l}\text { - Area (in square inches) devoted to content } \\
\text { promotion }\end{array}$ \\
\hline Story & Use of Jumps & Percentage of front page stories with jumps \\
\hline $\begin{array}{l}\text { Readability } \\
\text { Analysis }\end{array}$ & Story Title Length & $\begin{array}{c}\text { Average number of words of front } \\
\text { page story title }\end{array}$ \\
\hline
\end{tabular}

conglomerates. New Age is known to have an anti-establishment editorial policy. It is, thus, fitting that its slogan is "The Outspoken Daily." The Daily Star's slogan is "Your Right to Know" while the Daily Sun advocates "truth and impartiality". The other two do not use any slogan.

In terms of structure, except for Dhaka Tribune (which has a tabloid or compact size as the editor calls it), the other newspapers are broadsheets. Accordingly, Dhaka Tribune has the most number of pages and having only one section. The Daily Sun has, on the average, the most number of color pages (27) with Dhaka Tribune (24.8) and Independent (24.1) following closely. In terms of number of stories, Daily Sun has the most 
with an average of 166.2 stories per issue. After Daily Sun, Daily Star (123) and New Age (113.8) have the most stories per issue. For advertisements, the Daily Star defeated the others with an average of 44.4 advertisements per issue. The area devoted for classified ads is 245.4 square inches and display ads is 1038.4 square inches. The other newspapers are quite far in comparison with the Dhaka Tribune having the least with an average number of 9.67 advertisements per issue (Table 4).

\section{Content Diversity}

This sub-section describes the diversity of content in terms of section, source, news origin, geographic focus, treatment and theme. Moreover, it depicts the diversity of photographs to include those with faces that are visible, ethnic, Bengali, male, female and of children (Table 5).

Table 4. General profile of select English language newspapers.

\begin{tabular}{cccccc}
\hline Section & Daily Star & Daily Sun & $\begin{array}{c}\text { Dhaka } \\
\text { Tribune }\end{array}$ & Independent & New Age \\
\hline $\begin{array}{c}\text { Year } \\
\text { Established }\end{array}$ & 1991 & 2010 & 2013 & 1994 & 2003 \\
Slogan & $\begin{array}{c}\text { Your Right to } \\
\text { Know }\end{array}$ & $\begin{array}{c}\text { True and } \\
\text { Impartial }\end{array}$ & None & None & $\begin{array}{c}\text { The Outspoken } \\
\text { Daily }\end{array}$ \\
Size & Broadsheet & Broadsheet & $\begin{array}{c}\text { Tabloid } \\
\text { (Compact) }\end{array}$ & Broadsheet & Broadsheet \\
Owner & $\begin{array}{c}\text { Transcom } \\
\text { Group }\end{array}$ & $\begin{array}{c}\text { Bashundara } \\
\text { Group }\end{array}$ & $\begin{array}{c}\text { Gemcon } \\
\text { Group }\end{array}$ & $\begin{array}{c}\text { Beximco } \\
\text { Group }\end{array}$ & $\begin{array}{c}\text { Media New Age } \\
\text { Limited }\end{array}$ \\
Circulation & 41,150 & 28,150 & 23,100 & 28,600 & 25,520 \\
\hline
\end{tabular}

Table 5. Structure comparison of English language newspapers in November 2015.

\begin{tabular}{cccccc}
\hline Structure & Daily Star & Daily Sun & Dhaka Tribune & Independent & New Age \\
\hline $\begin{array}{c}\text { Average Number of } \\
\text { Pages }\end{array}$ & 24.6 & 27.6 & 35.2 & 24 & 21.3 \\
$\begin{array}{c}\text { Average Number of } \\
\text { Stand Alone Sections }\end{array}$ & 1.47 & 2.4 & 0.13 & 1.4 & 1.5 \\
$\begin{array}{c}\text { Average Number of } \\
\text { Stories }\end{array}$ & 123 & 166.2 & 85.2 & 109 & 113.8 \\
$\begin{array}{c}\text { Average Number of Full } \\
\text { Color Pages }\end{array}$ & 17.5 & 27 & 24.8 & 24.1 & 13 \\
$\begin{array}{c}\text { Average Number of } \\
\text { Advertisements }\end{array}$ & 44.4 & 18.7 & 9.67 & 29.6 & \\
$\begin{array}{c}\text { Average Area (in square } \\
\text { inches) for Classified } \\
\text { Ads }\end{array}$ & 245.4 & 111.5 & 3.83 & 225.4 & 14.85 \\
$\begin{array}{c}\text { Average Area (in square } \\
\text { inches) for Display Ads }\end{array}$ & $1,038.4$ & 469.5 & 426.75 & 889.85 & 762.6 \\
\hline
\end{tabular}


All select newspapers have the following sections in all issues in November 2015front, sports, editorial/opinion and international. Sections at least three newspapers have all the time are arts and entertainment, nation/country, business and city. The other sections that appear from time to time in the select newspapers include comics, lifestyle, youth, education, fashion, food computer and technology and science and health. The Daily Star sometimes has special sections on books and motoring while the Daily Sun at times has a travel section (Table 6).

In analyzing the front page stories of the select newspapers, the authors found out that majority of sources cited were officials or celebrities (62.2 to 80.9 percent). Ordinary people were seldom used as news sources ( $0.59 \%$ to $10 \%)$. In addition, a sizeable number of sources were not identified (13\% to $33 \%)$. In terms of gender, there were a lot more identifiably male sources $(42.98 \%$ to $59 \%)$ compared to identifiably female sources $(5.2 \%$ to $10 \%)$ (Table 7 ).

Most of the front page stories in the select newspapers in November 2015 came from staff $(20 \%$ to $53.6 \%)$ and byline (18\% to $69 \%)$. However, there is a large proportion of

Table 6. Section-wise inventory comparison of English language newspapers in November 2015 (in percent).

\begin{tabular}{|c|c|c|c|c|c|}
\hline Sections & Daily Star & Daily Sun & $\begin{array}{l}\text { Dhaka } \\
\text { Tribune }\end{array}$ & Independent & New Age \\
\hline Front & $100 \%$ & $100 \%$ & $100 \%$ & $100 \%$ & $100 \%$ \\
\hline Editorial/Opinion & $100 \%$ & $100 \%$ & $100 \%$ & $100 \%$ & $100 \%$ \\
\hline International & $100 \%$ & $100 \%$ & $100 \%$ & $100 \%$ & $100 \%$ \\
\hline Sports & $100 \%$ & $100 \%$ & $100 \%$ & $100 \%$ & $100 \%$ \\
\hline City & $100 \%$ & $100 \%$ & $0 \%$ & $100 \%$ & $6.7 \%$ \\
\hline $\begin{array}{c}\text { Arts and } \\
\text { Entertainment }\end{array}$ & $100 \%$ & $100 \%$ & $100 \%$ & $23 \%$ & $100 \%$ \\
\hline Nation/Country & $90 \%$ & $100 \%$ & $100 \%$ & $100 \%$ & $100 \%$ \\
\hline Business & $90 \%$ & $100 \%$ & $87 \%$ & $100 \%$ & $100 \%$ \\
\hline Comics & $77 \%$ & $100 \%$ & $100 \%$ & $0 \%$ & $0 \%$ \\
\hline Motoring & $17 \%$ & $0 \%$ & $0 \%$ & $0 \%$ & $0 \%$ \\
\hline Lifestyle & $13 \%$ & $0 \%$ & $13 \%$ & $0 \%$ & $23 \%$ \\
\hline Youth-oriented & $13 \%$ & $13 \%$ & $30 \%$ & $13 \%$ & $23 \%$ \\
\hline Education & $13 \%$ & $7 \%$ & $33 \%$ & $0 \%$ & $10 \%$ \\
\hline Books & $13 \%$ & $0 \%$ & $0 \%$ & $0 \%$ & $0 \%$ \\
\hline Fashion & $10 \%$ & $7 \%$ & $13 \%$ & $0 \%$ & $13 \%$ \\
\hline $\begin{array}{c}\text { Computer and } \\
\text { Technology }\end{array}$ & $10 \%$ & $7 \%$ & $33 \%$ & $0 \%$ & $10 \%$ \\
\hline Science and Health & $3 \%$ & $93 \%$ & $10 \%$ & $13 \%$ & $13.5 \%$ \\
\hline Food & $3 \%$ & $3 \%$ & $30 \%$ & $0 \%$ & $13 \%$ \\
\hline Travel & $0 \%$ & $7 \%$ & $0 \%$ & $0 \%$ & $6.7 \%$ \\
\hline
\end{tabular}


news stories originating from news agencies or service ( $2.37 \%$ to $24.6 \%)$. It should be noted that $24.6 \%$ of stories in the Independent have unknown origins. Also, in the Daily Sun, readers $(0.45 \%)$ contributed front page stories (Table 8 ).

The geographic focus of front page stories in select newspapers was on the capital ( $20.72 \%$ to $70.2 \%)$ or the nation $(5.2 \%$ to $48.8 \%)$. At times, the geographic focus is on the division $(2.22 \%$ to $15.77 \%)$, international $(8.9 \%$ to $14 \%)$ and South Asia (2.7\% to $11 \%)$. In terms of front page story treatment, Dhaka Tribune (41\%) and New Age (30.9\%) gave more emphasis to news analysis while Independent $(88.2 \%)$ focused more on hard news. The Daily Star (40.0\%) and Dhaka Tribune (35.6\%) placed stress on news analysis. Commentaries and featured news did not figure prominently in the front pages of the select newspapers in November 2015 (Table 9).

Table 7. Front page story source diversity comparison of English language newspapers in November 2015 (in percent).

\begin{tabular}{cccccc}
\hline Section & Daily Star & Daily Sun & Dhaka Tribune & Independent & New Age \\
\hline $\begin{array}{c}\text { Unidentified } \\
\text { Sources }\end{array}$ & $27.7 \%$ & $27 \%$ & $33 \%$ & $13 \%$ & $29 \%$ \\
Officials/Celebrities & $62.2 \%$ & $75 \%$ & $63 \%$ & $80.9 \%$ & $69 \%$ \\
Ordinary People & $0.59 \%$ & $4.9 \%$ & $9.2 \%$ & $10 \%$ & $8.6 \%$ \\
Identifiably Male & $55 \%$ & $59 \%$ & $42.98 \%$ & $56.8 \%$ & $45 \%$ \\
Identifiably Female & $10 \%$ & $8.1 \%$ & $5.7 \%$ & $5.2 \%$ & $7.1 \%$ \\
\hline
\end{tabular}

Table 8. Front page news origin comparison of English language newspapers in November 2015 (in percent).

\begin{tabular}{cccccc}
\hline Section & Daily Star & Daily Sun & Dhaka Tribune & Independent & New Age \\
\hline Staff & $50.45 \%$ & $48.4 \%$ & $20 \%$ & $53.6 \%$ & $44 \%$ \\
Byline & $31.53 \%$ & $28 \%$ & $69 \%$ & $18 \%$ & $30.1 \%$ \\
$\begin{array}{c}\text { News Agency/ } \\
\text { Service }\end{array}$ & $17.12 \%$ & $17.6 \%$ & $11 \%$ & $2.37 \%$ & $24.6 \%$ \\
Unknown & $0.9 \%$ & $5 \%$ & $0 \%$ & $24.6 \%$ & $1.3 \%$ \\
Reader & $0 \%$ & $0.45 \%$ & $0 \%$ & $0 \%$ & $0 \%$ \\
\hline
\end{tabular}

Table 9. Front page geographic focus comparison of English language newspapers in November 2015 (in percent).

\begin{tabular}{cccccc}
\hline Section & Daily Star & Daily Sun & Dhaka Tribune & Independent & New Age \\
\hline National & $37.8 \%$ & $21.3 \%$ & $48.8 \%$ & $5.2 \%$ & $23.7 \%$ \\
Capital & $20.72 \%$ & $52.0 \%$ & $28.8 \%$ & $70.2 \%$ & $31.4 \%$ \\
Division & $15.77 \%$ & $7.7 \%$ & $2.2 \%$ & $8.5 \%$ & $3 \%$ \\
International & $11.7 \%$ & $9 \%$ & $8.9 \%$ & $8.5 \%$ & $14 \%$ \\
South Asia & $2.7 \%$ & $4.1 \%$ & $7.8 \%$ & $4.3 \%$ & $11 \%$ \\
Other & $11.3 \%$ & $5.9 \%$ & $3.3 \%$ & $2.8 \%$ & $16.5 \%$ \\
\hline
\end{tabular}


In comparing the theme of front page stories, it was apparent that the New Age (69\%), Independent (64\%), Dhaka Tribune (60\%) and Daily Sun (39\%) preferred themes on politics, war and government. As opposed, the Daily Star (34\%) gave more emphasis on police, crime, courts and legal stories during the period. All newspapers placed front page stories on sports (3\% to $4.6 \%$ ) and on natural disasters, environment and weather $(0.5 \%$ to $4 \%)$. It should be noted that the Daily Star featured a variety of themes in its front page stories. In a way, this demonstrated greater diversity given that themes may range from business to entertainment, science to education, and religion to food.

Looking at photograph diversity, all select newspapers more or less followed the same trend. About a third of photographs (29.45\% to $31.22 \%$ ) had visible faces and these visible faces were mostly Bengali (25.4\% to $27.5 \%)$. Only the Daily Star and Independent showed a few ethnic faces. In addition, there was a greater percentage of male faces only ( $20.5 \%$ to $28 \%$ ) compared to female faces only ( $2.6 \%$ to $8.3 \%)$. The percent of photographs with male and females faces ranged from $10.1 \%$ to $12.61 \%$. Dhaka Tribune did not have any photograph of children while New Age had the most (3.79\%) (Table 10 and Table 11).

Use of Visuals: This sub-section illustrates the use of visuals in the select newspapers in the month of November 2015, particularly in terms of graphs, photographs and

Table 10. Front page story treatment comparison of English language newspapers in November 2015 (in percent).

\begin{tabular}{cccccc}
\hline Section & Daily Star & Daily Sun & Dhaka Tribune & Independent & New Age \\
\hline Hard News & $46.1 \%$ & $67.9 \%$ & $18.9 \%$ & $88.2 \%$ & $50.4 \%$ \\
$\begin{array}{c}\text { News Analysis } \\
\text { Investigative }\end{array}$ & $40.0 \%$ & $29.0 \%$ & $35.6 \%$ & $6.2 \%$ & $15.4 \%$ \\
News & $9.4 \%$ & $1.4 \%$ & $41 \%$ & $0 \%$ & $30.9 \%$ \\
Commentary & $2.3 \%$ & $1.4 \%$ & $0 \%$ & $5.2 \%$ & $0.4 \%$ \\
Featured News & $2.2 \%$ & $0 \%$ & $4.4 \%$ & $0 \%$ & $2.9 \%$ \\
\hline
\end{tabular}

Table 11. Front page story theme comparison of English language newspapers in November 2015 (in percent).

\begin{tabular}{cccccc}
\hline Section & Daily Star & Daily Sun & Dhaka Tribune & Independent & New Age \\
\hline $\begin{array}{c}\text { Police/Crime/ } \\
\text { Courts/Legal }\end{array}$ & $34 \%$ & $25 \%$ & $29 \%$ & $21.8 \%$ & $16 \%$ \\
$\begin{array}{c}\text { Politics/War/ } \\
\text { Government }\end{array}$ & $16 \%$ & $39 \%$ & $60 \%$ & $64 \%$ & $69 \%$ \\
Sports & $3.6 \%$ & $3 \%$ & $3 \%$ & $4.6 \%$ & $3 \%$ \\
$\begin{array}{c}\text { Natural Disasters/ } \\
\text { environment/ } \\
\text { weather }\end{array}$ & $0.5 \%$ & $3 \%$ & $4 \%$ & $1.4 \%$ & $1 \%$ \\
Others & $45.4 \%$ & $28 \%$ & $3 \%$ & $6.2 \%$ & $11 \%$ \\
\hline
\end{tabular}


listings. Table 12 indicated the percent of front pages with graphics and photographs of the select newspapers in November 2015 (Table 12).

As can be gleaned from Table 13, the Daily Star used graphics in all its front pages in November 2015. This was followed by Dhaka Tribune (60\%) and Independent (30\%). All newspapers used color graphics-no black and white ones. In terms of photographs, the Daily Star utilized photographs in $80 \%$ of its front pages; devoting an average area per day of 83.1 square inches. This was followed by Daily Sun (51\% with an average area of 37.07 square inches), Dhaka Tribune (38\% with an average area of 16.04 square inches) and Independent (31\% with an average area of 31.1 square inches). All newspapers utilized only color photographs and devoted $7 \%$ to $20 \%$ of their total front page space to photographs.

Table 12. Front page photo diversity comparison of English language newspapers in November 2015 (in percent).

\begin{tabular}{cccccc}
\hline Section & Daily Star & Daily Sun & Dhaka Tribune & Independent & New Age \\
\hline Visible Faces & $30.19 \%$ & $30.2 \%$ & $31.22 \%$ & $29.45 \%$ & $29.8 \%$ \\
Bengali Faces & $26.6 \%$ & $27 \%$ & $27.5 \%$ & $27.27 \%$ & $25.4 \%$ \\
$\begin{array}{c}\text { Male Faces } \\
\text { Only }\end{array}$ & $20.5 \%$ & $28 \%$ & $25.4 \%$ & $26.7 \%$ & $23.6 \%$ \\
$\begin{array}{c}\text { Female Faces } \\
\text { Only }\end{array}$ & $8.3 \%$ & $2.6 \%$ & $5.82 \%$ & $4.55 \%$ & $6.2 \%$ \\
$\begin{array}{c}\text { Male and } \\
\text { Female Faces }\end{array}$ & $12.61 \%$ & $11 \%$ & $10.1 \%$ & $11.1 \%$ & $11 \%$ \\
$\begin{array}{c}\text { Ethnic Faces } \\
\text { Only }\end{array}$ & $0.41 \%$ & $0 \%$ & $0 \%$ & $0.5 \%$ & $0 \%$ \\
$\begin{array}{c}\text { Children Faces } \\
\text { Only }\end{array}$ & $1.38 \%$ & $1.4 \%$ & $0 \%$ & $0.36 \%$ & $3.79 \%$ \\
\hline
\end{tabular}

Table 13. Percentage of front pages with graphics and photos (comparison of English language newspapers) in November 2015.

\begin{tabular}{cccccc}
\hline Section & Daily Star & Daily Sun & Dhaka Tribune & Independent & New Age \\
\hline Graphics & $100 \%$ & $16.67 \%$ & $60 \%$ & $30 \%$ & $10 \%$ \\
Color Graphics & $100 \%$ & $16.67 \%$ & $60 \%$ & $30 \%$ & $10 \%$ \\
Photographs & $80 \%$ & $51 \%$ & $38 \%$ & $31 \%$ & $21 \%$ \\
Color Photographs & $80 \%$ & $51 \%$ & $38 \%$ & $31 \%$ & $21 \%$ \\
$\begin{array}{c}\text { Average Area of } \\
\text { photographs per } \\
\text { day (in square } \\
\text { inches) }\end{array}$ & 83.1 & 37.07 & 16.04 & 31.1 & 22.03 \\
$\begin{array}{c}\text { Percentage of } \\
\text { Total Area for } \\
\text { Photographs }\end{array}$ & $20.0 \%$ & $14.0 \%$ & $10.0 \%$ & & \\
\hline
\end{tabular}


In terms of number, the Dhaka Tribune (32.8\%) and Daily Star (27.4\%) had more listings on sports while New Age (47.5\%) had more on stocks. The Independent (28.6\%) and Daily Sun (25.0\%) had more listings on entertainment, which included television and movie schedules. There were also listings on community announcements and obituaries. In terms of area allocation (in square inches), New Age (84.5\%), Independent (58.8\%) and Daily Sun (56.0\%) allocated greater space for stocks. Dhaka Tribune (57.3\%) concentrated on sports listings while Daily Star had a better balance of listings-entertainment (33.9\%), sports (29.5\%) and others (24.6\%). These included horoscopes, crosswords, comics, weather information, etc. (Table 14 and Table 15).

\section{Content Promotion}

This sub-section shows how the select newspaper promotes its content. Among the five, Dhaka Tribune did the most promotion with 551 instances allocated in 3183 square inches. This was followed by Daily Sun (281 instances in 2250 square inches) and Independent (159 occurrences in 1985.5 square inches). New Age did the least promotions with only 175 cases in 538 square inches. In terms of number of cases, all newspapers promoted the most their content for that day-Dhaka Tribune (91.5\%), Independent

Table 14. Listings structure comparison of English language newspapers in November 2015 by frequency.

\begin{tabular}{cccccc}
\hline Listings Type & Daily Star & Daily Sun & Dhaka Tribune & Independent & New Age \\
\hline Sports & $64(27.4 \%)$ & $9(2.9 \%)$ & $44(32.8 \%)$ & $6(3.8 \%)$ & $32(13.6 \%)$ \\
Stocks & $52(22.3 \%)$ & $76(24.5 \%)$ & $26(19.4 \%)$ & $28(17.6 \%)$ & $112(47.5 \%)$ \\
Entertainment & $35(15.0 \%)$ & $77(25.0 \%)$ & $4(2.9 \%)$ & $46(28.6 \%)$ & $31(13.1 \%)$ \\
Community & $30(12.9 \%)$ & $22(7.1 \%)$ & $30(22.4 \%)$ & $20(12.6 \%)$ & $30(12.7 \%)$ \\
Obituaries & $14(6.0 \%)$ & $5(1.5 \%)$ & $0(0 \%)$ & $9(5.7 \%)$ & $0(0 \%)$ \\
Others & $38(16.3 \%)$ & $121(39.0 \%)$ & $30(22.4 \%)$ & $50(31.5 \%)$ & $31(13.1 \%)$ \\
Total & $233(99.9 \%)$ & $310(100 \%)$ & $134(99.9 \%)$ & $159(99.8 \%)$ & $236(100 \%)$ \\
\hline
\end{tabular}

Table 15. Listings structure comparison of English language newspapers in November 2015 by Area (in square inches).

\begin{tabular}{cccccc}
\hline Type & Daily Star & Daily Sun & $\begin{array}{c}\text { Dhaka } \\
\text { Tribune }\end{array}$ & Independent & New Age \\
\hline Entertain-ment & $711.5(33.9 \%)$ & $2201(19.3 \%)$ & $33(2.8 \%)$ & $3064(27.9 \%)$ & $390(7.9 \%)$ \\
Sports & $619(29.5 \%)$ & $216(1.9 \%)$ & $676(57.3 \%)$ & $146(1.3 \%)$ & $152.5(3.1 \%)$ \\
Community & $90(4.3 \%)$ & $124(1.0)$ & $95(8.0 \%)$ & $45(0.4 \%)$ & $82(1.7 \%)$ \\
Obituaries & $84.5(4.0 \%)$ & $39(0.3 \%)$ & $0(0 \%)$ & $118(1.1 \%)$ & $0(0 \%)$ \\
Stocks & $78(3.7 \%)$ & $6396(56.0 \%)$ & $156(13.2 \%)$ & $6434(58.8 \%)$ & $4158(84.5 \%)$ \\
Others & $516(24.6 \%)$ & $2430(21.3 \%)$ & $220(18.6 \%)$ & $1132(10.3 \%)$ & $138((2.8 \%)$ \\
Total & $2099(100 \%)$ & $11,406(99.8 \%)$ & $1180(99.9 \%)$ & $10,939(99.8 \%)$ & $4920.5(100 \%)$ \\
\hline
\end{tabular}


(84.9\%), Daily Sun (76.9\%), Daily Star (64.3\%) and New Age (60.6\%). New Age (21.7\%) and Daily Star (21.4\%) did the most promotion for its website content. New Age (17.7\%) and Daily Star (9.3\%) gave the most general promotions (highlighting the paper as a whole).

In terms of area, Daily Star had the most balanced promotion. It had designated spaces for different types of promotion-general (39.8\%), same day content (31.3\%), website $(18.5 \%)$ and upcoming content $(10.4 \%)$. New Age had some balance with its promotion of general content (28.2\%), same day content (55.2\%) and website content (16.6\%). The Daily Sun and Dhaka Tribune were focused on promoting same day content and website content. The Independent's content promotion was almost solely on same day content (91.4\%). Dhaka Tribune and New Age did not promote at all upcoming content (Table 16 and Table 17).

\section{Story Readability Analysis}

This sub-section reviews story readability in terms of jumps and title length. Basically, all select newspapers utilized a high percentage of jumps (front stories continued on another page). Jumps usually have a negative effect on readability. In terms of front page article title length, the Daily Star (with an average of 5.28 words) has the shortest; followed by Independent (with an average of 5.52 words). New Age has the longest with

Table 16. Content promotion structure comparison of English language newspapers in November 2015 by frequency count.

\begin{tabular}{cccccc}
\hline Content Type & Daily Star & Daily Sun & Dhaka Tribune & Independent & New Age \\
\hline General & $13(9.3 \%)$ & $12(4.3 \%)$ & $6(1.1 \%)$ & $6(3.8 \%)$ & $31(17.7 \%)$ \\
$\begin{array}{c}\text { Same Day } \\
\text { Content }\end{array}$ & $90(64.3 \%)$ & $216(76.9 \%)$ & $504(91.5 \%)$ & $135(84.9 \%)$ & $106(60.6 \%)$ \\
$\begin{array}{c}\text { Upcoming } \\
\text { Content }\end{array}$ & $7(5.0 \%)$ & $17(6.0 \%)$ & $0(0 \%)$ & $4(2.5 \%)$ & $0(0 \%)$ \\
Website & $30(21.4 \%)$ & $36(12.8 \%)$ & $41(7.4 \%)$ & $14(8.8 \%)$ & $38(21.7 \%)$ \\
Total & $140(100 \%)$ & $281(100 \%)$ & $551(100 \%)$ & $159(100 \%)$ & $175(100 \%)$ \\
\hline
\end{tabular}

Table 17. Content promotion structure comparison of English language newspapers in November 2015 by area (in square inches).

\begin{tabular}{cccccc}
\hline Content Type & Daily Star & Daily Sun & Dhaka Tribune & Independent & New Age \\
\hline General & $419(39.8 \%)$ & $108(4.8 \%)$ & $7(0.2 \%)$ & $41.5(2.1 \%)$ & $152(28.2 \%)$ \\
$\begin{array}{c}\text { Same Day } \\
\text { Content }\end{array}$ & $330(31.3 \%)$ & $1622(72.1 \%)$ & $2939(92.3 \%)$ & $1815(91.4 \%)$ & $297(55.2 \%)$ \\
$\begin{array}{c}\text { Upcoming } \\
\text { Content } \\
\text { Website }\end{array}$ & $110(10.4 \%)$ & $90(4.0 \%)$ & $0(0 \%)$ & $78(3.9 \%)$ & $0(0 \%)$ \\
Total & $105(18.5 \%)$ & $430(19.1 \%)$ & $237(7.5 \%)$ & $51(2.6)$ & $89(16.6 \%)$ \\
\hline
\end{tabular}


an average of 6.86 words. As a rule of thumb, shorter titles are considered more readable than longer ones (Table 18 and Table 19).

\section{Summary, Conclusion and Recommendations}

In summary, the general structure and readability characteristics of the select English language newspapers for the month of November 2015 were as follows:

- Except for the Dhaka Tribune (with a tabloid or compact size), the other newspapers are broadsheets. The average number of pages ranged from 21 to 35 . The average number of full color pages ranged from 13 to 27 . The average area (in square inches) of classified ads was from 3.83 to 245.4. Display ads covered (in square inches) from 426.75 to 1038.4 .

- The newspapers had in all its issues the following sections-front, editorial/opinion, international and sports. After these, the following sections appeared most of the time-arts and entertainment, nation/country and business.

- The diversity of front page story sources was not much given that newspapers mostly quoted officials, celebrities and male. There are a substantial number of sources who remained unidentified. Photograph diversity was not much as well since visible faces were more of Bengali and male only faces.

- Most of the stories were written by staff and byline and, to some extent, by news agencies. The geographic focus was mostly national and capital. The story treatment was mostly hard news and news analysis. However, Dhaka Tribune and New Age had made inroads with investigative news. The front page story theme focused more on politics/war/government and police/crime/courts/legal.

Table 18. Percentage of Front page stories with "Jump" comparison of English language newspapers in November 2015.

\begin{tabular}{cccccc}
\hline Week & Daily Star & Daily Sun & Dhaka Tribune & Independent & New Age \\
\hline Week One & $96.15 \%$ & $84.78 \%$ & $100.0 \%$ & $89.83 \%$ & $98.21 \%$ \\
Week Two & $86.0 \%$ & $89.8 \%$ & $93.75 \%$ & $85.96 \%$ & $98.18 \%$ \\
Week Three & $94.92 \%$ & $93.44 \%$ & $90.48 \%$ & $86.67 \%$ & $100.0 \%$ \\
Week Four & $93.62 \%$ & $89.8 \%$ & $91.30 \%$ & $88.24 \%$ & $98.28 \%$ \\
Month Average & $92.67 \%$ & $89.46 \%$ & $93.88 \%$ & $87.68 \%$ & $98.67 \%$ \\
\hline
\end{tabular}

Table 19. Front page article title length comparison of English language newspapers in November 2015 (in number of words).

\begin{tabular}{cccccc}
\hline Week & Daily Star & Daily Sun & Dhaka Tribune & Independent & New Age \\
\hline Week One & 5.58 & 6.62 & 6.13 & 5.07 & 6.95 \\
Week Two & 5.5 & 6.55 & 6.25 & 5.22 & 7.04 \\
Week Three & 5.05 & 5.51 & 6.1 & 5.54 & 6.61 \\
Week Four & 5 & 6.06 & 6.3 & 6.26 & 6.84 \\
Month Average & 5.28 & 6.19 & 6.20 & 5.52 & 6.86 \\
\hline
\end{tabular}


- In using visuals, the Daily Star always utilized graphics and usually had photographs in its front page-devoting $20 \%$ of the page to photographs. The use of visuals was done to a lesser extent in other newspapers. For listings, the Daily Sun and Independent made use of this the most; the focus of which was on stocks.

- The Dhaka Tribune had the most content promotion; concentrating mostly on same day content. Daily Star, Daily Sun and New Age gave some attention to general promotion, upcoming content promotion and website promotion.

- The newspapers made extensive use of jumps-an average of $87.68 \%$ to $98.67 \%$ of front page stories. Also, the average front page story title length ranged from 5.28 to 6.86 words.

In conclusion, it can be stated that English language newspapers in Bangladesh can improve on readability characteristics as measured by diversity, use of visuals, content promotion and story readability. However, as shown in the research findings, there had been several good practices as follows:

- All newspapers made use of full color pages. Also, the Daily Star was conscious in extensively utilizing graphics and photographs. It also had the best balance in terms of photograph diversity as it had the most photographs with female and children faces only. It also had the most balanced listings composed of entertainment, sports and others.

- In terms of sections, all newspapers had basic staples-front, editorial/opinion, international and sports. It also featured extensively sections on arts and entertainment, nation/country and business. They, however, need to diversify sources more and utilized stories written by readers in its front pages.

- It is likewise noteworthy that the Dhaka Tribune and New Age published a substantial number of investigative news in its front page. This brought about a wider variety of story treatments-hard news and news analysis being the standard.

- The Daily Star had the most diverse front page story themes. It was not limited to politics/war/government and police/crime/courts/legal. It had a lot of stories on entertainment, business, science, education, etc.

- The Daily Star had the most balanced content promotion with allocations for general, same day, upcoming and website content. New Age did not have promotion for upcoming content but had for the other types. The other newspapers were more focused on same day content.

- All newspapers can improve on using jumps. A great number of their front page stories utilized jumps. For article title length, all newspapers did these very well; the number of words ranging from 5.28 to 6.86 words on the average.

With these, the authors suggest the following recommendations. First, it would be good to repeat this study a few more times to clearly see the trends vis-a-vis readability characteristics of the select newspapers. Second, it would be beneficial if the readability of stories can be measured using any of the measurements such as Flesch Test, Gunning Fog Index or Cloze Procedure. This way, the ease of reading articles in the said newspapers would be included-not just the jumps and article title length. Third, it would be 
helpful if stories appearing in other pages would be included for analysis. In this study, only the front page stories were included. Lynch \& Peer (2002) actually suggested a sample rate of $60 \%$ of stories.

\section{Study Limitations}

The study had limitations in terms of its method and design. For one, its measure for story readability was based on jumps and title length. It did not measure the ease of reading of the article text. Second, only the stories appearing in the front page of the select newspapers were included for analysis. Third, the paper did not look into the impact of the select newspapers on the reader or the interactions between the newspaper and the reader.

\section{References}

Associates for Company and Population Research (2002). National Media Survey. Dhaka: Bangladesh Centre for Communication Programs \& Social Marketing Company.

Bangladesh Literacy Survey (2010). Report on Bangladesh Literacy Survey. Bangladesh Bureau of Statistics.

http://203.112.218.65/WebTestApplication/userfiles/Image/SubjectMatterDataIndex/YB-2012. pdf

Coulson, D., \& Hansen, A. (1995). The Louisville Courier-Journal's News Content after Purchase by Gannett. Journalism and Mass Communication Quarterly, 72, 205-221. https://doi.org/10.1177/107769909507200117

Dale, E., \& Chall, J. S. (1949). The Concept of Readability. Elementary English, 26, 23.

Kondur, J. (2006). Using Part of Speech Structure of Text in the Prediction of Its Readability. Unpublished Master's Thesis, Arlington: University of Texas.

http://proquest.umi.com/pdqweb?did=1216761731\&sid=1\&Fmt=2\&clientld=46449\&PQT=309 \&VName $=$ PQD

Lynch, S., \& Peer, L. (2002). Analysing Newspaper Content: A How-To Guide. USA: Readership Institute.

Mahmud, S. (2013). The Transformation of the Bangladesh Press. In B. Shoesmith, \& J. W. Genilo (Eds.), Bangladesh's Changing Mediascape: From State Control to Market Forces. UK: Intellect Bristol.

McLaughlin, G. H. (1969). SMOG Grading: A New Readability Formula. Journal of Reading, 12, 639-646.

Meyer, P., \& Kim, K. H. (2003). Quantifying Newspaper Quality: "I Know It When I See It". https://books.google.ca/books?id=q0y4AwAAQBAJ\&pg=PA200\&lpg=PA200\&dq=Meyer, + P., $+\% 26+\mathrm{Kim},+\mathrm{K} .+\mathrm{H} .+(2003) .+$ Quantifying+Newspaper+Quality:+\%E2\%80\%9CI+Know $+\mathrm{It}+\mathrm{W}$ hen $+\mathrm{I}+$ See+It\%E2\%80\%9D\&source=bl\&ots=iplkiHaEGn\&sig=hWTn9IEIEeCMa5MJlyCgMg3 3hNk\&hl=en\&sa=X\&ved=0ahUKEwid6c3X25XRAhUF_4MKHahwA2kQ6AEIHDAA\#v=onep age\&q=Meyer\%2C\%20P.\%2C\%20\%26\%20Kim\%2C\%20K.\%20H.\%20(2003).\%20Quantifying\% 20Newspaper\%20Quality\%3A\%20\%E2\%80\%9CI\%20Know\%20It\%20When\%20I\%20See\%20It $\% \mathrm{E} 2 \% 80 \% 9 \mathrm{D} \& \mathrm{f}=$ false

Reza, S. M. S. and Haque, A. (2011). Campaign on Local Environmental Issues in Bangladesh Newspapers. Media Asia: An Asian Communication Quarterly, 38, 225-231.

Rezaei, A. A. (2000). The Validity of the Fog-Index of Readability. Journal of Humanities of Is- 
lamic Republic of Iran, 7, 17-27.

Richards, J. C., Platt, J., \& Platt, H. (1992). Longman Dictionary of Language Teaching and Applied Linguistics. London: Longman.

WAN-IFRA (2015). World Press Trends: News Revenues Shifts to New Sources. http://www.wan-ifra.org/press-releases/2015/06/01/world-press-trends-newspaper-revenues-s hift-to-new-sources

Wimmer, R. D., \& Dominick, J. R. (1997). Mass Media Research: An Introduction. Boston: Wadsworth Publishing.

Submit or recommend next manuscript to SCIRP and we will provide best service for you:

Accepting pre-submission inquiries through Email, Facebook, LinkedIn, Twitter, etc. A wide selection of journals (inclusive of 9 subjects, more than 200 journals)

Providing 24-hour high-quality service

User-friendly online submission system

Fair and swift peer-review system

Efficient typesetting and proofreading procedure

Display of the result of downloads and visits, as well as the number of cited articles Maximum dissemination of your research work

Submit your manuscript at: http://papersubmission.scirp.org/

Or contact ajc@scirp.org 